ELORE (ISSN 1456-3010), vol. $19-1 / 2012$.

Julkaisija: Suomen Kansantietouden Tutkijain Seura ry.

[http://www.elore.fi/arkisto/1_12/pk.pdf]

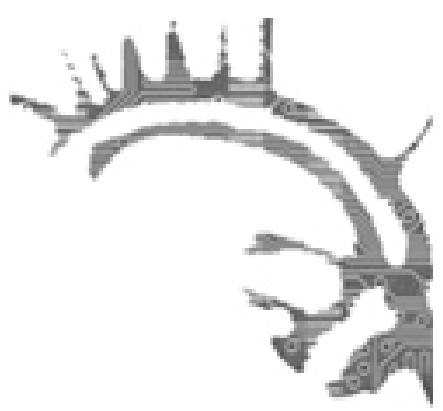

\title{
PÄÄKIRJOITUS
}

\section{MUUTOKSEN TUULIA}

\author{
Elina Hytönen ja Sofie Strandén-Backa
}

Elore sai alkunsa vuonna 1994 Joensuun yliopiston yhden laitoksen työntekijöiden ja tutkijoiden parissa (Pöysä 1994). Toimituksen jäsenet työskentelivät saman käytävän varrella ja tunsivat toisensa varsin hyvin jo ennen lehden toimintaa. Moni asia Eloren toimituksessa, kuten myös akateemisessa ympäristössä, on muuttunut sitten lehden ensimmäisten vuosien samalla, kun lehden toiminta on laajentunut huomattavasti kuluneiden 18 vuoden aikana. Nykyinen toimitus koostuu useiden yliopistojen tutkijoista eri puolilta Suomea ja myös Suomen rajojen ulkopuolella. Tästä numerosta eteenpäin Elorella on kaksi päätoimittajaa: Elina Hytönen ja Sofie Strandén-Backa. Elina toimii tutkijatohtorina Itä-Suomen yliopistossa ja tekee tällä hetkellä tutkimusta Englannissa, jossa hän vierailee Oxfordin yliopistossa ja King’s Collegessa Lontoossa. Sofie on lähtöisin Åbo Akademista ja on projektitutkijana Svenska Litteratursällskapet i Finlandissa, eli SLS:ssä. Eloressa työskennellään toisin sanoen nykyisin kaksikielisesti aivan käytännön tasolla.

Lehdestä on tullut selkeämmin kaksikielinen tieteellinen kanava, joka yhdistää alallaan sekä suomen- että ruotsinkieliset tutkijat ja akateemiset piirit. Toimituksen jäsenten maantieteellinen etäisyys toisistaan sekä monikielisyys asettavat lehdelle omat haasteensa, mutta tuo mukanaan myös oman rikkautensa. Olennaista lehden tekemiselle on kuitenkin kautta sen historian ollut toimituskunnan vapaaehtoistyö ja intohimoinen omistautuminen lehden toimittamiselle.

Lehden tarkoituksena on ollut tutkimusten vapaa julkaiseminen Internetissä niin sanotussa open access -muodossa. Open access -toiminta sekä tieteellisten lehtien 
Elina Hytönen ja Sofie Strandén-Backa: Muutoksen tuulia

hinnat ovat herättäneet viime aikoina kansainvälisessä mediassa huomiota ja muun muassa The Guardian lehti uutisoi huhtikuun lopussa Harvardin yliopiston ottaneen kantaa tieteellisten lehtien kustantajien ylläpitämiin huimiin hintoihin. Harvardin toiveena on ollut, että tutkijat julkaisisivat tutkimuksiaan yhä useammin open access -lehdissä ja säästäisivät näin kirjastojen kustannuksia. Taustalla on huoli siitä, että yliopistojen piirissä toimivat tutkijat tekevät vapaaehtoistyötä tieteellisille lehdille referoidessaan artikkeleita ja toimittaessaan lehtiä, mutta tämä ilmainen työ palautuu yliopistoille lehtien kalliina vuosikustannuksina. (Sample 2012.) Elore on toiminnallaan kulkenut tätä virtausta vastaan jo vuosia ja pyrkinyt tuomaan tieteellisiä artikkeleita, katsauksia, kirja-arvioita ja konferenssiraportteja helposti saataville. Haluaisimmekin kannustaa tutkijoita edelleen myös Suomessa käyttämään hyväkseen laajemman yleisön saatavilla olevia julkaisuväyliä.

Tarkoituksemme on oman päätoimittajakautemme aikana jatkaa Eloren kehittämistä yhä paremmaksi ja arvostetummaksi tieteelliseksi julkaisukanavaksi Pohjoismaiden alueella. Tämä vaatii lehden tiettyjen osa-alueiden uudelleenmäärittelyä ja muuttamista, mutta myös tiettyjen osa-alueiden (muun muassa katsauksien) kehittämistä. Yhtenä osana tätä kehitystyötä on ollut osallistuminen Julkaisufoorumi -hankkeeseen ja suomen- ja ruotsinkielisten tieteellisten lehtien luokituksen nostamiseen. Toivomme, että tämä ja muut muutokset houkuttelevat yhä laajemman lukija- ja kirjoittajakunnan Eloren äärelle tulevina vuosina.

Olemme erittäin iloisia, että voimme avata päätoimittajakautemme SKTS:n juhlavuotena hienolla teemanumerolla, jossa käsitellään idästä päin tulevia vaikutteita, siirtolaisia ja maahanmuuttajia. Antoisia lukuhetkiä!

\section{LÄHTEET}

PÖYSÄ, JYRKI 1994. Taustaa elektrolorismille. Elore, 1/1994.

SAMPLE, IAN 2012. Harvard University says it can't afford journal publisher's price. The Guardian, 24th of April 2012. <http://www.guardian.co.uk/science/2012/ apr $/ 24 /$ harvard-university-journal-publishers-prices? $\mathrm{fb}=$ native $\& \mathrm{CMP}=\mathrm{FBCNE}$ TTXT9038> [24.4.2012.]

FT Elina Hytönen toimii tutkijatohtorina Itä-Suomen yliopistossa ja tekee tällä hetkellä tutkimusta Englannissa, jossa här vierailee Oxfordin yliopistossa ja King's Collegessa Lontoossa. FT Sofie Strandén-Backa on lähtöisin Åbo Akademista ja on projektitutkijana Svenska Litteratursällskapet i Finlandissa, eli SLS:ssä. 